\title{
DETECTION OF TRYPSIN INHIBITOR IN SEEDS OF EUCALYPTUS UROPHYLLA AND ITS INFLUENCE ON THE IN VITRO GROWTH OF THE FUNGI PISOLITHUS TINCTORIUS AND RHIZOCTONIA SOLANI
}

\author{
Célia Regina Tremacoldi ${ }^{1}$; Sérgio Florentino Pascholati ${ }^{1 *}$
}

\author{
${ }^{1}$ Departamento de Entomologia, Fitopatologia e Zoologia Agrícola, Escola Superior de Agricultura Luiz de Queiroz, \\ Universidade de São Paulo, Piracicaba, SP, Brasil.
}

Submited: June 26, 2001; Returned to authors for corrections: October 18, 2002; Approved: December 05, 2002.

\begin{abstract}
Inhibitors of plant proteases can regulate the hydrolysis of proteins inside the cells and also participate in the mechanisms of plant defense against herbivore insects and pathogens. Here, we demonstrated that seeds of Eucalyptus urophylla exhibit activities of trypsin and papain inhibitors, two proteases commonly found in living cells. Low amounts of proteins of the crude protein extract of seeds and fractions partially purified by gel filtration, with inhibitory activity against trypsin, inhibited in vitro the mycelial growth of a compatible isolate of the ectomycorrhizal fungus Pisolithus tinctorius and allowed an unsatisfactory growth of another isolate from Pinus taeda, considered incompatible for this eucalyptus species. The same amounts of inhibitory proteins, when tested in vitro on the pathogen Rhizoctonia solani, did not exhibit any effect on the growth of the pathogen. These results indicate the existence of proteases inhibitors in seeds of $E$. urophylla which could influence the complex biochemical system that differentiates mechanisms of symbiosis and pathogenicity between plants and microorganisms.
\end{abstract}

Key words: protease, inhibitor, trypsin, Pisolithus tinctorius, Rhizoctonia solani

\section{INTRODUCTION}

Plants, microorganisms and animals contain proteins that exhibit the peculiar property of forming complexes with proteolytic enzymes, promoting the inhibition of their activity by competing for the catalytic site. These proteins are called protease inhibitors. Their molecular mass varies from 10 to 90 $\mathrm{kDa}$, and they exhibit high or no specificity to the target enzyme. Most of the protease inhibitors known and characterized in plants belong to the group of the serine-protease inhibitors, which includes trypsin (9).

The physiological role of plant protease inhibitors is not very clear. Besides regulating the hydrolysis of proteins inside the cell, they can participate in defense mechanisms of plants against herbivore insects and/or pathogens. For example, in interactions between plants and fungi, during the penetration and colonization processes, extracellular proteases of a pathogen would promote the hydrolysis of proteins of the cellular wall. Thus, protease inhibitors of the host plant could act directly against those enzymes, delaying the proteolysis of cellular walls and membranes, and reducing the cellular desorganization (10).

Differences in the accumulation of protease inhibitors and proteases in compatible and incompatible interactions between plants and microorganisms $(4,8)$ let us associate these groups of proteins to the resistance and susceptibility concepts, generating perspectives of a better understanding of the biochemical bases that govern the plant-pathogen interactions. However, there are not many studies showing the role of protease inhibitors in the mechanisms of plant defense against pathogens. For trees, even those cultivated in commercial scale, as Eucalyptus spp. and Pinus spp., there are no reports on the

* Corresponding author. Mailing address: Departamento de Entomologia, Fitopatologia e Zoologia Agrícola, ESALQ-USP. Caixa Postal 9. 13418900, Piracicaba, SP, Brasil. Tel.: (+5519) 3429-4124. Fax: (+5519) 3434-4839. E-mail: sfpascho@esalq.usp.br 
occurrence of protease inhibitors and, consequently, on the possible role of the inhibitors on pathogenic or symbiont fungi, as the ectomycorrhiza, present in all species of those plants.

In the present work, we studied the activity of protease inhibitors in seeds of E. urophylla and the influence of the trypsin inhibitor on the in vitro growth of compatible and incompatible isolates of the ectomycorrhizal fungus Pisolithus tinctorius. We also studied its influence on the growth of the pathogen Rhizoctonia solani, agent of damping-off in nursery plants.

\section{MATERIALS AND METHODS}

\section{Biological materials and chemical reagents}

The ectomycorrhizal fungus Pisolithus tinctorius, isolate 1604, obtained from Eucalyptus grandis (Rio Claro/SP/Brazil) and isolate 185, obtained from Pinus taeda (USA) were used in the biological assays. The pathogen Rhizoctonia solani was isolated from seedlings of Eucalyptus urophylla (SP/Brazil). Seeds of E. urophylla were obtained from the Institute of Forest Research at ESALQ/USP - Piracicaba, SP, Brazil. The chemicals bovine pancreas trypsin, chymotrypsin, Carica papaya papain, BAPNA ( $\alpha$-benzoyl-arginyl- $p$-nitroanilide), BTPNA ( $\alpha$-benzoyltyrosine- $p$-nitroanilide), Triton X-100, Dimethyl sulfoxide (DMSO), dithiothreitol (DTT) and Sephacryl S-100-HR were obtained from Sigma (USA).

\section{Extraction}

The crude protein extract was obtained from $10 \mathrm{~g}$ of $E$. urophylla seeds, disrupted in liquid nitrogen. A saline solution $(\mathrm{NaCl} 15 \% ; 1: 10 \mathrm{v} / \mathrm{v})$ was added to the powder and the suspension was kept under agitation during $1 \mathrm{~h}$, followed by centrifugation at $12,300 \mathrm{~g}\left(4^{\circ} \mathrm{C}\right)$ for $20 \mathrm{~min}$. The supernatant was collected and four volumes of cold acetone was added to it and centrifuged at $12,300 \mathrm{~g}\left(4^{\circ} \mathrm{C}\right)$ for $20 \mathrm{~min}$. After centrifugation, the pellet was mixed with distilled water $(1: 10 \mathrm{w} / \mathrm{v})$, maintained under agitation for $15 \mathrm{~min}$ and centrifuged at $12,300 \mathrm{~g}$ for $20 \mathrm{~min}$. The supernatant obtained represented the crude protein extract, from which the tests for protease inhibitory activity were accomplished. To eliminate the risk of a possible inhibition of the protease inhibitor activity because of the presence of lectins (proteins that can associate to carbohydrates), before the assay of inhibitory activity for any protease, the crude extract was heated at $70^{\circ} \mathrm{C}$ for $20 \mathrm{~min}(9)$, temperature that is supported by the protease inhibitors but not by the lectins (3).

\section{Measurement of trypsin, chymotrypsin and papain inhibitory activities}

To study the trypsin activity, volumes of $30,50,70,85,100$ and $150 \mu \mathrm{L}$ of the crude extract were incubated with $10 \mathrm{mg}$ of trypsin (diluted in $1 \mathrm{mM} \mathrm{HCl}$ ) and with variable volumes of the $0.1 \mathrm{M}$ Tris- $\mathrm{HCl}$ buffer, $\mathrm{pH} 8.0$, containing $0.01 \mathrm{M} \mathrm{CaCl}_{2}$, to make a final volume of $500 \mu \mathrm{L}$ in each test tube. This reaction mixture was pre-incubated by $10 \mathrm{~min}$ at $37^{\circ} \mathrm{C}$, and $500 \mu \mathrm{L}$ of the cromogenic substrate BAPNA ( $1 \mathrm{mM}$ in DMSO) were added to each tube, which was incubated for $40 \mathrm{~min}$ at $37^{\circ} \mathrm{C}$. The reaction was stopped by the addition of $500 \mu \mathrm{L}$ of acetic acid (30\% v/v) to each test tube. An enzyme activity of $100 \%$ was obtained by not adding the protein extract to the reaction mixtures. The controls for each volume of the extract tested were obtained by the addition of acetic acid just before the incubation with the substrate BAPNA (7). The experiment was repeated 4 times with 2 replicates for each volume of the extract tested. An average of the absorbance readings at $405 \mathrm{~nm}$ for the replicates was calculated and it produced a value that was the difference between the absorbance in the reaction tubes and their respective control test tubes. This value, for each volume of the extract, was subtracted of the value that represented $100 \%$ of enzyme activity, allowing the calculation of the residual activity of trypsin based upon $\mu \mathrm{L}$ of crude extract. The activity evaluation for the chymotrypsin inhibitor of the protein crude extract was accomplished in a similar way to that described for trypsin having BTPNA (1mM in DMSO) as the substrate for this protease. For the evaluation of the papain activity volumes of 100,150 and $200 \mu \mathrm{L}$ of the protein extract reacted with the substrate BAPNA, in presence of $0.2 \mathrm{M}$ sodium acetate buffer, $\mathrm{pH} 5.5$, added of $0.01 \%$ Triton X-100 and of $1 \mathrm{mM}$ DTT. Before the addition of papain to the test tubes containing the reaction mixture, the papain was pre-incubated with the buffer during 10 $\min$ at $37^{\circ} \mathrm{C}$.

\section{Gel filtration}

The crude extract was applied to a chromatography column $(60 \mathrm{~cm} \times 1.5 \mathrm{~cm})$ filled out with Sephacryl S-100-HR, equilibrated and eluted with $0.1 \mathrm{M}$ Tris-HCl buffer, $\mathrm{pH}$ 8.0. Samples of the extract $(1.5 \mathrm{~mL})$ were applied to the column and were eluted in a flow rate of $18 \mathrm{~mL} / \mathrm{h}$, with fractions of $1 \mathrm{~mL}$ collected every 3.3 $\mathrm{min}$. The void volume (Vo) of the column was determined by using $1 \mathrm{~mL}$ of blue dextran $(1 \mathrm{mg} / \mathrm{mL})$ under the same flow conditions.

\section{Activity of trypsin inhibitor in the fractions}

All the fractions obtained by gel filtration had the absorbance read at $280 \mathrm{~nm}$ in a spectrophotometer, and an aliquot of $50 \mu \mathrm{L}$ of each one was tested for trypsin inhibitory activity. These aliquots reacted with $300 \mu \mathrm{L}$ of $0.1 \mathrm{M}$ Tris- $\mathrm{HCl}$ buffer, $\mathrm{pH}$ 8.0, and $10 \mathrm{mg}$ of trypsin diluted in $1 \mathrm{mM} \mathrm{HCl}$. The incubation was carried out at $37^{\circ} \mathrm{C}$ for $10 \mathrm{~min}$, followed by the adition of $500 \mu \mathrm{L}$ of BAPNA for a new incubation in the same temperature during $40 \mathrm{~min}$. The reaction was stopped by the addition of $500 \mu \mathrm{L}$ of acetic acid $(30 \% \mathrm{v} / \mathrm{v})$. The inhibitory activity was calculated as the difference between the trypsin activity in the absence and in the presence of the fractions. The fractions with trypsin inhibitory activity superior to $50 \%$ were pooled. The concentration of proteins in the crude extract of seeds and in 
the several fractions was estimated by the method of Bradford (1), using bovine serum albumin as standard.

\section{Estimate of the molecular masses}

The standard curve for the calculation of the molecular masses of the fractions with inhibitory activity was obtained by using the kit MW-GF-70 (Sigma), with samples of $1.5 \mathrm{~mL}$ of bovine serum albumin $(5 \mathrm{mg} / \mathrm{mL})$, aprotinin $(3 \mathrm{mg} / \mathrm{mL})$, carbonic anidrase $(2 \mathrm{mg} / \mathrm{mL})$ and cytochrome $\mathrm{c}(2 \mathrm{mg} / \mathrm{mL})$, eluted in the $0.1 \mathrm{M}$ Tris- $\mathrm{HCl}$ buffer, $\mathrm{pH} 8.0$, in a flow rate of $0.3 \mathrm{~mL} / \mathrm{min}$, with fractions of $1 \mathrm{~mL}$ collected every $3.3 \mathrm{~min}$.

\section{Effect of the crude extract of seeds on the mycelial growth of $P$. tinctorius and $R$. solani isolates}

To test the in vitro effect of the protein crude extract of $E$. urophylla seeds on the growth of the symbiont $P$. tinctorius and on the pathogen $R$. solani both fungi were grown inside Petri dishes of $5 \mathrm{~cm}$ diameter. The isolate 1604 of P. tinctorius is considered highly compatible for ectomycorrhiza formation in E. urophylla (2) while the isolate 185 is seen as incompatible because it does not produce typical ectomycorrhiza in the same eucalyptus species.

A disk of mycelia of each fungus was placed onto PDA (potato dextrose agar) medium, $\mathrm{pH}$ 6.7, previously flooded with 21 and $47 \mu \mathrm{g}$ of protein, after sterilization through Millipore filter $0.2 \mu \mathrm{m}$. Each concentration and the control (to which the protein extract was not increased) had 3 replicates. The volume of the extract corresponding to the wanted protein concentration was adjusted so that each plate contained $7 \mathrm{~mL}$ of final volume (PDA+ protein extract added). In each plate, after the hardening of the growth medium, was placed a disk of $4 \mathrm{~mm}$ diameter of $P$. tinctorius or $R$. solani from colonies 30 and 40 days old, respectively. The incubation was carried out at $28^{\circ} \mathrm{C}$ in the darkness. Fungal growth was evaluated through the measurement of colony diameter daily until the mycelial growth in the control plates for each species had covered all the medium. The experiment was repeated once.

Effect of fractions with trypsin inhibitory activity on the mycelial growth of $P$. tinctorius and $R$. solani isolates

The fractions obtained by gel filtration chromatography of the crude seed extract that exhibited inhibition of the trypsin activity superior to $50 \%$ were pooled and tested against the mycelial growth of $P$. tinctorius isolates 1604 and 185 and $R$. solani. The procedure used for growth, incubation time and incorporation of the protein fractions into the medium were identical to those carried out with the crude extract. Control treatment was represented by growth medium without adding the fractions, while treatments included media with aliquots from the fractions having $1,3,7,15$ and $20 \mu \mathrm{g}$ of protein for each plate of $5 \mathrm{~cm}$ diameter with a $7.0 \mathrm{~mL}$ final volume. The experiment was repeated once.

\section{RESULTS}

The crude extract from E. urophylla seeds showed the existance of trypsin and papain inhibitors (Fig. 1), but did not exhibit inhibitory activity against chymotrypsin (data not shown). The amount of proteins in this extract was equal to $3.5 \%$ in relation to the fresh weight of the seeds and it was kept inside a freezer until the use. The activities of the inhibitors were expressed in percentage of residual trypsin or papain activity.

Gel chromatography of the crude seed extract showed that peak I, based upon the absorbance at $280 \mathrm{~nm}$ (Fig. 2 - see arrow), exhibited trypsin inhibitory activity equivalent to $40 \%$ of the residual activity.

The crude extract of E. urophylla seeds, based upon two protein concentrations ( 21 and $47 \mu \mathrm{g}$ ), when incorporated into the growth medium, caused complete growth inhibition of $P$. tinctorius compatible isolate 1604 (Fig. 3 - A) and allowed an unsatisfactory growth of the incompatible isolate 185 (Fig. 3 - B).
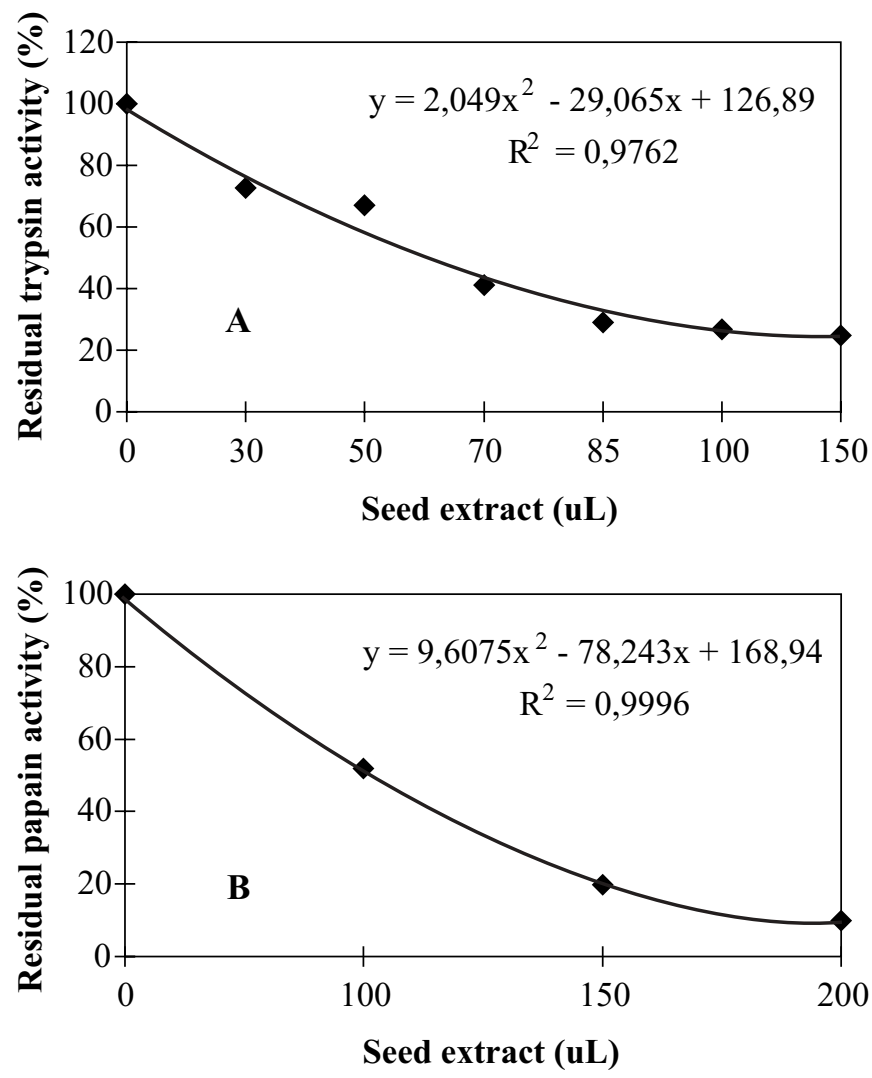

Figure 1. Inhibition profile of the trypsin (A) and papain (B) activities by the crude protein extract from seeds of Eucalyptus urophylla. The synthetic substrate BAPNA $(1 \mathrm{mM})$ was incubated with bovine trypsin or papain and increasing amount of seed extract at $37^{\circ} \mathrm{C}$ for $40 \mathrm{~min}$. 


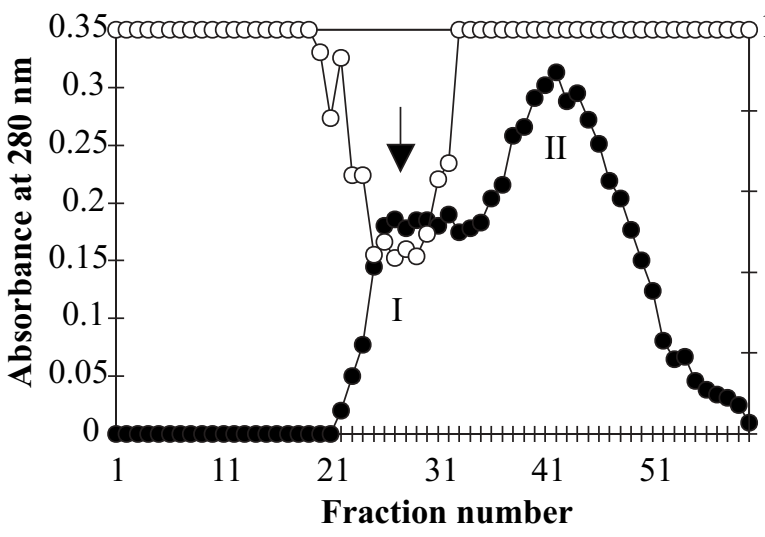

Figure 2. Gel filtration chromatography through Sephacryl S100-HR of the crude seed extract of Eucalyptus urophylla. The column $(60 \times 1.5 \mathrm{~cm})$ was equilibrated and eluted with $0.1 \mathrm{M}$ Tris-HCl buffer, $\mathrm{pH}$ 8.0. Fractions of $1 \mathrm{~mL}$ were collected at a flow rate of $18 \mathrm{~mL} / \mathrm{h}$ and $50 \mu \mathrm{L}$ were incubated with $1 \mathrm{mMBAPNA}$ and $10 \mathrm{mg}$ of bovine trypsin, $\mathrm{pH} 8.0$ at $37^{\circ} \mathrm{C}$. Numbers I and II refer to the peaks of absorbance at $280 \mathrm{~nm}(\bullet)$ and the black arrow indicates the minimum value of $\%$ residual trypsin activity/ $\mu \mathrm{L}$ of fraction $(\mathrm{O})$.

At the end of the experiment, disks from the medium containing mycelia of the fungi in the two treatments were transferred to Petri dishes, containing PDA medium to evaluate the fungistatic or fungicidal effect. Since the mycelium in the disks from the isolates 1604 and 185 did not grow, the effect of the crude extract was considered as fungistatic (data not shown). The $R$. solani isolate did not exhibit changes in the normal pattern or growth speed (Fig. 3 - C). When the partially purified fractions for the trypsin inhibitor activity, were used in the experiments (protein concentration equal to 15 and $20 \mu \mathrm{g}$ ), they exhibited the same effects on growth of the symbiont and pathogenic fungi (Fig. 4). The molecular mass of the pooled fractions (Fig. 2 - peak I), with trypsin inhibitory activity superior to $50 \%$, was estimated in $76 \mathrm{kDa}$ (data not shown).

\section{DISCUSSION}

The low residual activity of trypsin (around 25\%) in the presence of the seed extract of $E$. urophylla made it possible to check for chymotrypsin inhibitory activity, since these two groups of protease inhibitors are not commonly associated (6). Thus, it can be assumed that chymotripsin inhibitors do not occur in seeds of E. urophylla. Although the inhibition of the papain activity was around $90 \%$, we decided to test initially the effects of the trypsin inhibitor, since it is the most studied among the inhibitors of plant proteases. The studies were carried out using extracts from E. urophylla seeds due to the difficulty to
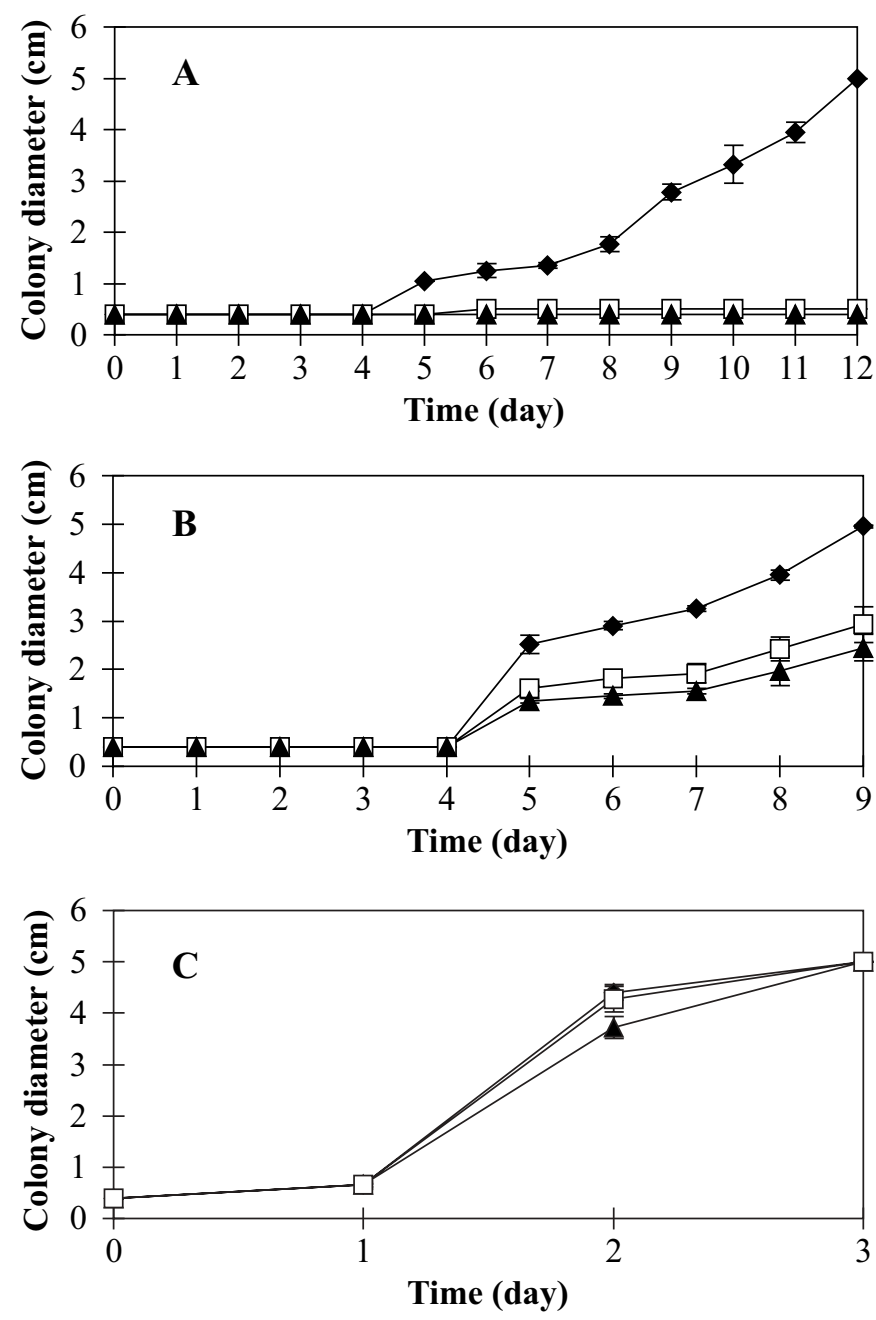

Figure 3. Effect of different protein concentrations of the crude seed extract of Eucalytus urophylla on the growth of Pisolithus tinctorius isolate 1604 (A) during 12 days, on P. tinctorius isolate 185 (B) during 9 days, and on Rhizoctonia solani (C) during 3 days of incubation in PDA medium at $28^{\circ} \mathrm{C}$. Protein concentration: $\diamond=0 \mu \mathrm{g} ; \square=21 \mu \mathrm{g} ; \boldsymbol{\Delta}=47 \mu \mathrm{g}$. Bars represent mean \pm SE.

obtain from the roots the adequate amount of protein for the biological and biochemical assays. In addition, seeds are easier to be obtained compared to roots and most of the studies already accomplished on inhibitors of plant proteases were centered around seeds, especially from leguminous plants (5).

The observation of the growth pattern of $P$. tinctorius and $R$. solani isolates in the presence of the crude extract from seeds and partially purified fractions with trypsin inhibitory activity allowed important considerations. For both, the symbiont and the pathogenic fungus, the growth curves exhibited the same patterns when the crude extract or the partially purified fractions 

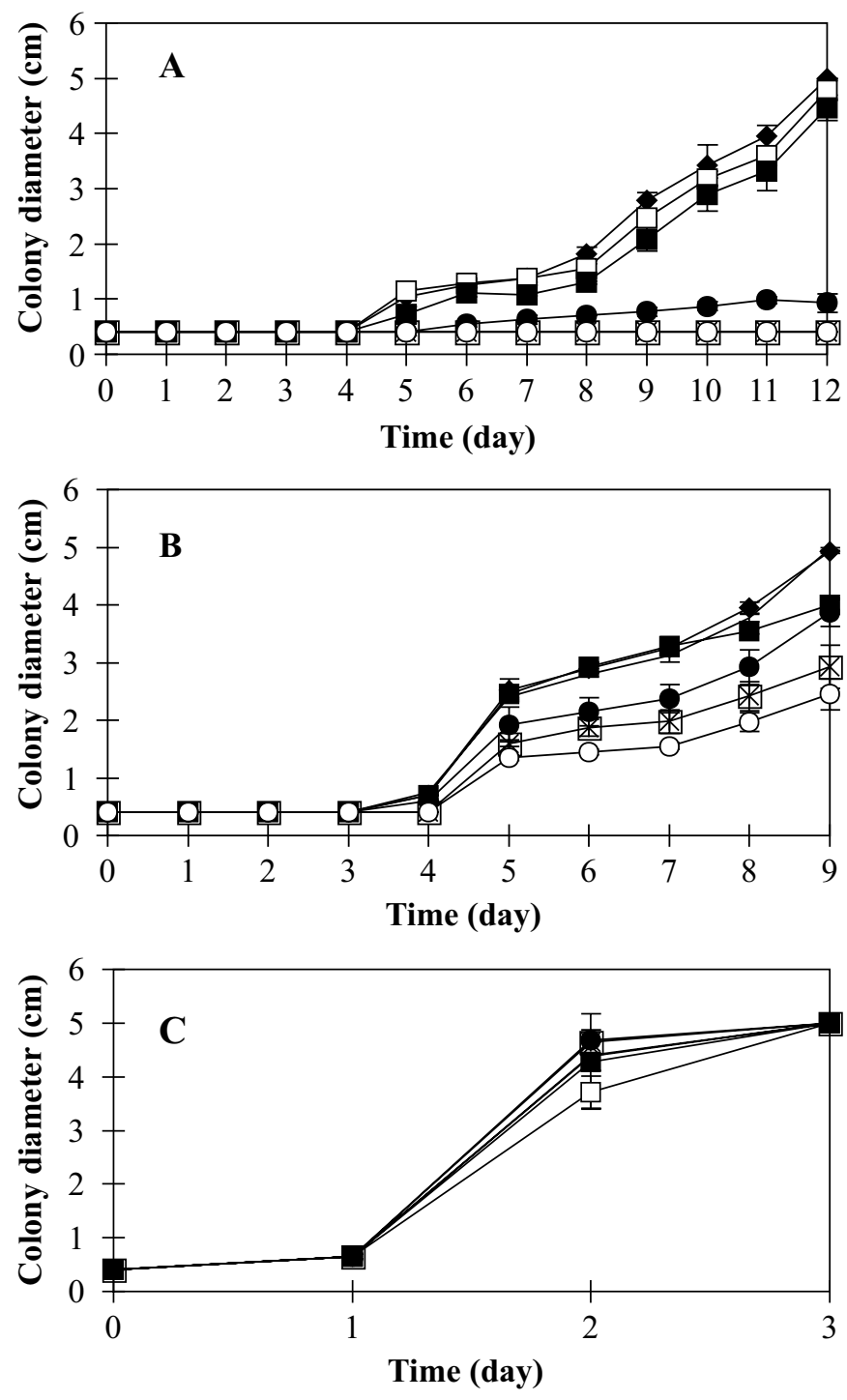

Figure 4. Effect of different protein concentrations of partially purified seed fractions of Eucalyptus urophylla, obtained by gel filtration, with trypsin inhibitory activity on the mycelial growth of Pisolithus tinctorius isolate 1604 (A) during 12 days, isolate 185 (B) during 9 days and on Rhizoctonia solani (C) during 3 days of incubation in $\mathrm{PDA}$ at $28^{\circ} \mathrm{C}$. Protein concentration: $\diamond=0 \mu \mathrm{g} ; \square=1 \mu \mathrm{g} ; \boldsymbol{\square}=3 \mu \mathrm{g} ; \boldsymbol{\bullet}=7 \mu \mathrm{g} ; \mathrm{X}=15 \mu \mathrm{g}$; $\mathrm{O}=20 \mu \mathrm{g}$. Bars represent mean $\pm \mathrm{SE}$.

were used, demonstrating that there is a correlation between the inhibition of the fungal growth and the presence of the trypsin inhibitor. The differencial effect of the trypsin inhibitor from E. urophylla seeds on $P$. tinctorius and $R$. solani growth is another interesting aspect, since this protein group can participate in the complex biochemical mechanism of recognition of a symbiont or a pathogen microorganism by the host plant. However, future studies are necessary to verify the activity of trypsin inhibitor in roots of $E$. urophylla infected or not with symbionts and pathogens to reach specific conclusions regarding the involvement of the inhibitor in the recognition process. Another aspect to be considered is the effect of the trypsin inhibitor on the growth of the two isolates of the ectomycorrhizal fungus, where the isolate 185 (incompatible) was able to grow even in an unsatisfactory way in presence of the crude extract or partially purified fractions (protein concentrations equal to 21 e $47 \mu \mathrm{g}$ in Fig. 3 and 15 e $20 \mu \mathrm{g}$ in Fig. 5 ) while the growth of isolate 1604 (compatible) was completelly inhibited in the same protein concentrations. However, these results still do not allow us to make any association between the compatibility of the symbiont and the trypsin inhibitor activity in the host plant.

The results presented open new perspectives for the study of proteins related to the recognition processes between pathogens and symbionts for eucalyptus species, since for these interactions protease inhibitors and proteases were not previously reported in the literature.

\section{RESUMO}

\section{Descoberta de inibidor de tripsina em sementes de Eucalyptus urophylla e sua influência sobre o crescimento in vitro dos fungos Pisolithus tinctorius e Rhizoctonia solani}

Os inibidores de proteases de plantas podem regular a hidrólise de proteínas no interior celular e também participar de seus mecanismos de defesa contra insetos herbívoros e patógenos. No presente trabalho, nós demonstramos que sementes de Eucalyptus urophylla apresentam atividades de inibidores de tripsina e papaína, duas proteases comumente encontradas em seres vivos. Pequenas quantidades de proteínas do extrato protéico bruto de sementes e de frações parcialmente purificadas por filtração em gel, com atividade inibitória de tripsina, inibiram o crescimento micelial in vitro de um isolado compatível do fungo ectomicorrízico Pisolithus tinctorius e permitiram um crescimento insatisfatório de outro isolado de Pinus taeda, considerado compatível para esta espécie de eucalipto. As mesmas concentrações de proteínas, quando testadas in vitro sobre o patógeno Rhizoctonia solani, não demonstraram qualquer efeito sobre seu crescimento. Estes resultados indicam a existência de inibidores de proteases em sementes de E. urophylla, os quais poderiam influenciar o complexo sistema bioquímico que diferencia mecanismos de simbiose e patogenicidade entre plantas e microrganismos.

Palavras-chave: protease, inibidor, tripsina, Pisolithus tinctorius, Rhizoctonia solani. 


\section{REFERENCES}

1. Bradford, M.M. A rapid and sensitive method for the quantitation of microgram quantities of protein utilizing the principle of proteindye binding. An. Biochem., 72: 248-254, 1976.

2. Galli, M.A. Influence of organic matter sources on formation of ectomycorrhizas in Eucalyptus citriodora seedlings inoculated with Pisolithus tinctorius. Piracicaba, Brazil, 1996, 90p. (Ph.D. thesis. ESALQ/São Paulo State University).

3. Gatehouse, A.M.R.; Powell, K.S.; Peumans, W.J.; Van Damme, E.J.M.; Gatehouse, J.A. Insecticidal properties of plant lectins: their potential in plant protection. In: Pusztai, A.; Bardocz, S. (eds). Lectins: biomedical perspectives, Taylor and Francis, London, 1995, p.35-57.

4. Giri, A.P.; Harsulkar, A.M.; Patankar, A.G.; Gupta, V.S.; Sainani, M.N.; Deshpande, V.V.; Ranjekar, P.K. Association of induction of protease and chitinase in chickpea roots with resistance to Fusarium oxysporum f. sp. ciceri. Plant Pathol., 47: 693-699, 1998.
5. Kalume, D.E.; Sousa, M.V.; Morthy, L. Purification, characterization, sequence determination and mass spectrometric analysis of a trypsin inhibitor from seeds of the brazilian tree Dipteryx alata (Leguminosae). J. Prot. Chem., 14: 685-693, 1995.

6. Laskowski, M.; Kato, I. Protein inhibitors of proteinases. Annu. Rev. Biochem., 49: 593-626, 1980.

7. Lin, J.Y.; Chu, S.C.; Wu, H.C.; Hsieh, Y.S. Trypsin inhibitor from the seeds of Acacia confusa. J. Biochem., 110: 879-883, 1991.

8. Peng, J.H.; Black, L.L. Increased proteinase inhibitor activity in response to infection of resistant tomato plants by Phytophthora infestans. Phytopathology, 66: 958-963, 1976.

9. Richardson, M. Seed storage proteins: The enzyme inhibitors. In: Dey, P.M.; Harborne, J.B. (eds). Methods in plant biochemistry, Vol. 5, Academic Press, New York, 1991. p.259-306.

10. Ryan, C.A. Proteinase inhibitors in plants: genes for improving defenses against insects and pathogens. Annu. Rev. Phytopathol., 28: 425-449, 1990. 